\title{
Comparative Study on the Knowledge, Attitude and Practice of Self Breast Examination and Breast Cancer Screening Between First and Second Class Women of Kitwe District
}

\author{
Kennedy Zimba ${ }^{1,}$, , Alfred Matafwali Sichilima ${ }^{2}$ \\ ${ }^{1}$ Department of Public Health, Michael Chilufya Sata School of Medicine, Copperbelt University, Ndola, Zambia \\ ${ }^{2}$ Department of Biological Sciences, School of Mathematics \& Natural Sciences, Copperbelt University, Kitwe, Zambia
}

Email address:

kennedyzimba@gmail.com (K. Zimba)

${ }^{*}$ Corresponding author

To cite this article:

Kennedy Zimba, Alfred Matafwali Sichilima. Comparative Study on the Knowledge, Attitude and Practice of Self Breast Examination and Breast Cancer Screening Between First and Second Class Women of Kitwe District. International Journal of Clinical Oncology and Cancer Research. Vol. 3, No. 5, 2018, pp. 59-71. doi: 10.11648/j.ijcocr.20180305.11

Received: October 31, 2018; Accepted: December 3, 2018; Published: March 2, 2019

\begin{abstract}
Breast cancer (BC) is the second leading cause of cancer related deaths in both developing and developed countries. One major contributor to high morbidity is late diagnosis which is due to lack of knowledge of the risk factors, causes, early signs and symptoms and simple screening tools like Self Breast Examination (SBE) and Clinical Breast Examination (CBE). The aim of this study was to compare level of knowledge of BC, CBE and SBE as well as attitude and practice towards CBE and SBE between women in rural and urban areas. A cross-sectional study was conducted among 300 women who were residents of Parklands (Urban area) and Kawama (Rural area). Equal numbers of women from each area were recruited into the study. All the 300 questionnaires were properly filled and returned. Data was entered and analysed in SPSS version 20.0 software. The majority of participants (34.3\%) were between the age of 36 and 45 years and resided in Parklands (59.2\%). All the participants $(100 \%)$ had heard about CBE but only $87.3 \%$ of these respondents were able to explain correctly what it is $(53.7 \%$ urban and $42.7 \%$ rural). Of all the respondents, $57.7 \%$ had heard about Self Breast Examination before the day of the interview. The most common source of information of CBE was 'friends' (77\%). Furthermore, $49.7 \%$ of the subjects had good knowledge about BC and CBE, while 28\% had poor knowledge. Of all the women, $45 \%$ had good knowledge about BSE while $53.7 \%$ had poor knowledge. In addition, $96.3 \%$ of the respondents showed good attitude toward $\mathrm{CBE}$ and 3.7\% showed poor attitude. Level of education showed significant relationship with Practice of CBE (P - value: $0.00)$, Practice of SBE (P- Value: 0.00), level of knowledge of CBE (P - value: 0.00$)$ and level of knowledge of SBE (P Value: 0.00). Lastly, attitude towards CBE did not seem to show any significant relationship with practice of CBE (P - Value: 0.522). The findings of the study showed that most of rural than urban women had poor knowledge about BC, CBE and SBE. Educational programs on breast cancer and SBE should be conducted in print and electronic media using the local languages to reach out to the women in rural areas.
\end{abstract}

Keywords: Breast Cancer, Clinical Breast Examination, Self-Breast Examination, Knowledge, Attitude, Practice, Kitwe

\section{Introduction}

\subsection{Background}

Breast cancer $(\mathrm{BC})$ is a malignant tumour in the glandular tissues of the breast. Such tumours, also called carcinomas, are the product of the process called carcinogenesis, which is basically the process of transformation of normal cells to neoplastic cells by causing permanent genetic alterations, most frequently to the cell repair genes such as p53 and hence there is no control in the proliferation of cells. This enables a single abnormal cell to multiply at a rapid rate 
greater than the physiological rate [1]. The major pathological effects of breast carcinomas are distraction of normal breast tissues, pathological increase in size of the breast over time, metastasis to distant vital organs like the lungs, liver, bones and brain. With nearly 1.7 million new cases diagnosed in 2012, breast cancer remains one of the most common cancer in women, cervical cancer ranking in first place [2]. Thus, BC is a major worldwide public health problem, its prevalence is mostly high in developed countries such as USA, where it was estimated that about 203, 500 new cases are diagnosed and about 40,000 women die each year from cancer originating in the breast [3]. However, due to the availability of efficient large scale screening methods and techniques and advanced awareness and educative programs on breast cancer, a greater number of cases have been treated in recent years, hence the mortality from $\mathrm{BC}$ has rapidly declined in these regions [4]. A study conducted in Canada estimated that about 19, 000 new cases of BC are diagnosed in Canada each year, and 5, 300 Canadian women die from the disease annually [5].

\subsection{Risk Factors to Breast Cancer}

Risk factors are anything that increases the probability of any given women developing breast cancer. Most important risk factors for breast cancer are non-modifiable, such as age, family history, and medical history [6]. However, there are some risk factors that can controlled such as weight, diet, physical exercise, alcohol consumption and exposure to oestrogen. The precise etiopathogenesis of breast cancer is not well known. However, studies suggest that several categories of women are at increased risk for the disease such as: -

i. Those with long menstrual history (menarche at 12 years and menopause at 50 years);

ii. Those who never gave birth or who waited until after age 30 to have children;

iii. Those who have used birth control pills or hormone replacement therapy (HRT).

Such risk factors, all of which relate to hormone-based life events, suggest that breast cancer is somehow affected by prolonged exposure to female sex hormones, such as oestrogen [7]. The first drop in breast cancer cases in the USA was reported in 2006 and this was attributed to the reduction in the use of HRT by millions of American women to treat symptoms of menopause in 2000. In addition, women with a history of breast cancer in the family are also at greater risk [8]. About 5 percent of all breast cancers have been attributed to a mutated, or structurally altered, gene known as BRCA1.

\subsection{Sypmtoms of Breast Cancer}

Breast cancer like any other autonomous malignant or nonmalignant growth may or may not cause any symptoms initially. Pathologically breast cancer may start as a small lump, however, in most cases this lump may be too small for women to feel or to cause any unusual changes that she can notice herself. These lumps are usually painless, hard, and have uneven edges. Nevertheless, cancerous lumps can also be tender, soft, and rounded. Thus it is important to have anything unusual checked by a physician. And often an abnormal area may turn up on a screening mammogram, which leads to further testing. According to the American Cancer Society (ACS), any of the following unusual changes in the breast can be a symptom of breast cancer:

i. Swelling of all or part of the breast

ii. Skin irritation or dimpling

iii. Breast pain

iv. Nipple pain or nipple turning inward

v. Redness, scariness, or thickening of the nipple or breast skin

vi. Nipple discharge other than breast milk

vii. A lump in the underarm area

However, these changes can also be signs of less serious conditions that are not cancerous, such as an infection or a cyst.

\subsection{Treatment}

Treatment of breast cancer depends on a woman's age and health as well as the type, extent, and location of the tumour, and if the cancer has remained in the breast or has spread to other parts of the body [9]. Treatment may include:
i. Surgery
ii. Radiation
iii. Chemotherapy
iv. Hormone therapy
v. Combination of any of the above

\subsection{Prognosis}

Like any other cancer, prognosis sorely depends on two most important factors which are the type and the stage of the cancer at the time of diagnosis. The most frequently used prognosis method is the five- year survival rate, which is a measure used to estimate the probability of any given patient to survive for five years or above from the time of diagnosis of the disease. According to the ACA, the five-year survival rate for an American woman diagnosed with localized breast cancer increased from 72 percent in the 1940s to 96 percent in the late 1990s. However, for those who were diagnosed with breast cancer in its late stages, it had already metastasized to distant organs and the five- year survival rate dropped significantly [10].

For cancers, the earlier it is detected, the more effective the treatment will be and also the higher the chances of survival. There are many screening methods for breast cancer, and these include self-breast examination (SBE), clinical breast examination (CBE), and mammography, which are usually done in combination. The method which has been proven to be effective among these is mammography, but its only costeffective and feasible in countries with good health infrastructure. SBE and CBE are recommended in developing countries because they are easy to do, and no specific equipment are required. The purpose of $\mathrm{SBE}$ and $\mathrm{CBE}$ is to 
make women familiar with both the appearance and feel of their breasts as early as possible, so that they can easily detect any changes. SBE is not often done by women, even though it's a simple, quick and cost-effective procedure. It appears that many women do not know how to do it so they either do it incorrectly or not at all. For CBE, many women either feel uncomfortable being examined so they shun going for regular check-ups. The purpose of this study was to compare the knowledge, attitude, and practice of SBE and CBE between females in urban areas and those in rural areas in order to determine the differences if they exist and to generate data that may be useful in coming up with interventions aimed at creating awareness of SBE and CBE as screening methods for early detection of breast cancer.

\subsection{Statement of Problem}

Studies show that breast cancer is the second leading cause of cancer related deaths in both developing and developed countries. According to different research studies conducted, it has been established that the incidence of breast cancer cases and their related deaths and mobility is on a rampant increase in developing countries like Zambia. This has been attributed to recent adoption of western culture lifestyles such as poor diets (fast foods) and short lactation periods. Nevertheless, one major contributor is late diagnosis, which is due to lack of knowledge of the disease by some women and inefficient and non-cost effective screening tools in clinics and hospitals. The economical and psychological burden of late stage breast cancer directly and indirectly affects the economy of the country in that breast cancer is indiscriminate it thus affects working class and non-working class women hence resulting in low productivity of the country.

Basically, there is need to implement and support already existing efficient and cost effective methods of detecting breast cancer in its early stage, since one of the major contributing factor to its prognosis is the stage at the time of diagnosis. The two most viable and cost effective early detection methods are self-breast examination and clinical breast examination. The former involves the women herself examining her breast monthly and reporting immediately to a doctor any abnormalities like a lump or breast pain while the latter involves a trained clinician like a nurse examining the patients' breast regardless of her presenting complaints.

\subsection{Key Terms}

Breast cancer:

Breast cancer is a malignant neoplastic disease of the breast tissue [11].

Knowledge:

This refers to information and skills obtained through experience or education [12]. In this study knowledge referred to participant's awareness of breast cancer, its risk factors, causes, signs and symptom and prevention. It also referred to respondent's awareness of CBE and SBE.

Self-Breast Examination (SBE)
This is an option of examination given to women starting in their 20s to help them become familiar with how their breasts look and feel, and to report any new changes to a health professional. It is the skill of examination done by women to familiarize themselves with the way their breasts feel [13].

\section{Clinical Breast Examination (CBE):}

This refers to breast examination performed by a welltrained healthcare worker when screening a woman for breast cancer.

Self-Breast Examinations (SBE):

practice in this study referred to participants' actual performance of self-breast examination.

\section{Etiology:}

The science and study of causes of diseases and their mode of operation.

Prognosis:

Forecast of the probable course and/or outcome of a disease.

Symptom:

Any morbid phenomenon or departure from the normal in structure, function, or sensation, experienced by the patient and indicative of disease.

Metastasis:

The spread of a disease process from one part of the body to another, as in the appearance of neoplasms in parts of the body remote from the site of primary tumour; results from dissemination of tumour cells by the lymphatic or blood vessels or by direct extension through serous cavities or subarachnoid.

\section{Mammogram:}

Radiologic examination of the female breast with equipment and techniques designed to screen for cancer.

Brca 1:

A tumour suppressor gene on chromosome 17 at locus $17 \mathrm{q} 21$, that encodes $\mathrm{p} 53$ protein, which prevents cells with damaged DNA from dividing.

\subsection{Theoretical Framework}

The Health Belief Model (HBM) was chosen as a theoretical framework for this research study and it has important applications to the practice of Clinical Breast Examination and Self Breast Examination. The HBM was one of the first models to adapt theories from the behavioral sciences in order to examine health related problems and is still one of the most widely recognized and used models in health behavior applications [14]. This model was originally introduced by a group of psychologists in the 1950's to help explain why people would or would not use available preventive services, such as chest x-rays for tuberculosis screening and immunizations for influenza [14]. The HBM has six concepts which are Perceived susceptibility to an illness, perceived seriousness of the illness, perceived benefits for the presumed action, Perceived barriers for presumed action, Confidence in one's ability and Health motivation [15, 14]. According to [16] the model is well researched and has been used to explain many health 
behaviors [15], asserts that the HBM explains the possible reasons why people do or do not do available preventive services or activities. The Health Belief Model can be applied to breast cancer screening. According to HBM a woman who perceives that she is susceptible to breast cancer is a serious disease, is more likely to perform regular breast examination. Similarly, a woman who has an internal cue (bodily perception) or who had been exposed an external cue (positive influence of healthcare provider or media) would be more likely to adopt SBE as she wants to improve her health and is confident of positive results $[17,18]$. The HBM helped place this research within the body of knowledge related to Breast Cancer, Clinical Breast Examination and Self Breast Examination since many previous researchers have used the model to assess knowledge, attitude and practice of women towards $\mathrm{BC}, \mathrm{CBE}$ and $\mathrm{SBE}$.

\subsection{Methodolgy}

An exploratory quantitative, cross sectional comparative study was conducted in Kitwe district, Copperbelt province. Two residential areas were selected with reference to Kitwe town Centre, to represent Kitwe urban and Kitwe rural. Parklands and kawama respectively were selected. Permission to conduct the study was obtained from Tropical Disease Research Centre's Ethics Review Committee at Ndola Teaching Hospital, provincial medical office and from Kitwe district health office. Furthermore, Informed consent was obtained from the individual women who participated in the study. A systematic random sampling technique was employed to select the households. A three section, semistructural questionnaire was developed and was used when conducting a face to face interview with each of the 300 participants. After the data was collected, raw data was edited for completeness and consistency, categorised and coded and entered in SPSS version 21.0, a statistical, data packaging and processing software. Further analysis was done by utilizing Chi-square and determining the possible association between different variables. P-values less than 0.05 were considered to be statistically significant.

\section{Results and Data Analysis}

\subsection{Demographics}

The study was conducted on 300 women of which 150 resided in Parklands, an urban area and the other 150 stayed in Kawama, a rural area. Age of participants ranged from 18 to 60 years. The mean age of women from Parklands was 37.26 years (S.D: 8.902 years) while that of women from Kawama was 40.08 years (S.D: 10.766 years). Overall the mean age of participants was 38.67 years (S.D 9.963).

\subsubsection{Frequency Distribution of Age and Residence}

Majority of the participants $103(34.3 \%)$ were between the ages of 36 and 45 years. Most of these resided in Parklands (59.2\%). 40 (13.3\%) were between $16-25$ years $(42.5 \%$ from Parklands and 57.5\% from Kawama), 56 (18.7\%) were between 26 and 35 years (69.6\% from Parklands and 30.4\% from Kawama) and 101 (33.7\%) were above the age of 45 (32.7\% from Parklands and $67.3 \%$ from Kawama).

Table 1. Distribution of Age and Residence.

\begin{tabular}{lllll}
\hline & & \multicolumn{2}{l}{ Residence } & \\
\cline { 3 - 4 } & & $\begin{array}{l}\text { Parklands } \\
\text { (Urban) }\end{array}$ & $\begin{array}{l}\text { Kawama } \\
\text { (Rural) }\end{array}$ & Total \\
\hline \multirow{3}{*}{ Age } & $16-25$ & 17 & 23 & 40 \\
Groups & $26-35$ & 39 & 17 & 56 \\
& $36-45$ & 61 & 42 & 103 \\
Total & 46 and above & 33 & 68 & 101 \\
\hline
\end{tabular}

\subsubsection{Frequency Distribution of Marital Status}

The number of married participants was 234 (78\%), that is $56.8 \%$ from Parklands and 43.2\% from Kawama, 26 (8.7\%) were single $(30.8 \%$ from Parklands and $69.2 \%$ from Kawama), 21 (7\%) were divorced (23.8\% from Parklands and $76.2 \%$ from Kawama), $18(6 \%)$ were widows $(16.7 \%$ from Parklands and $83.3 \%$ from Kawama) and $1(0.3 \%)$ were on separation (100\% from Parklands and 0\% from Kawama). Chi square value: 22.984 and $\mathrm{P}$ - value: 0.000

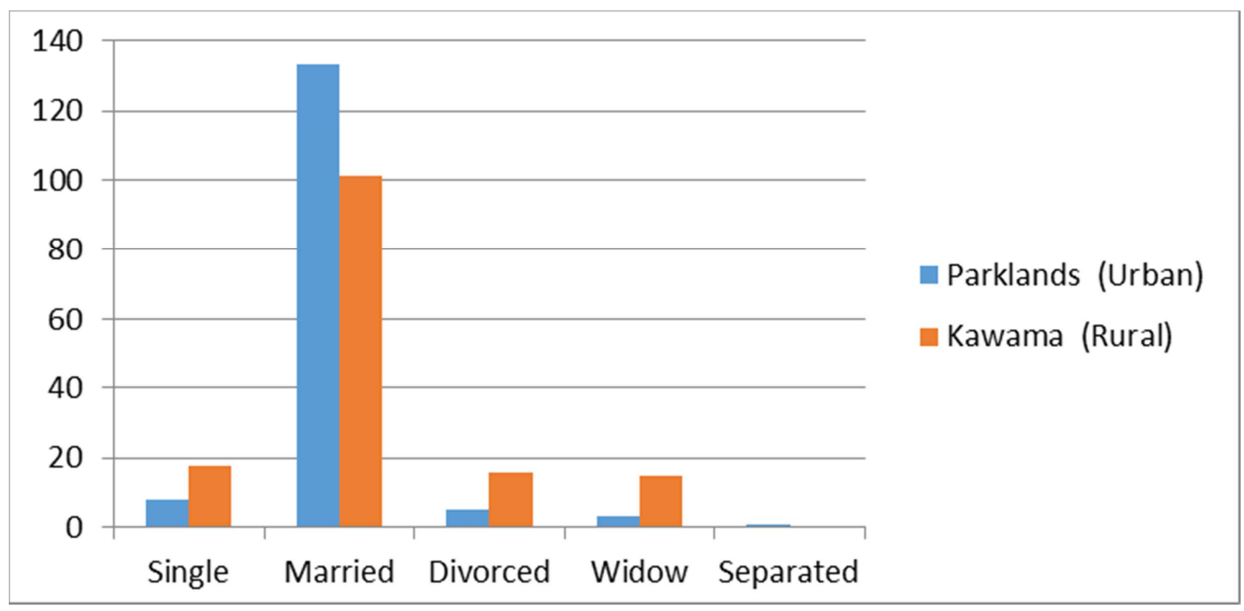

Figure 1. Distribution of Marital Status. 


\subsubsection{Frequency Distribution of Level of Education}

Table 2. Distribution of Level of Education.

\begin{tabular}{lllll}
\hline & & Residence & \\
\cline { 3 - 4 } & & $\begin{array}{l}\text { Parklands } \\
\text { (Urban) }\end{array}$ & $\begin{array}{l}\text { Kawama } \\
\text { (Rural) }\end{array}$ & Total \\
\hline Maximum & None & 0 & 8 & 8 \\
level of & Primary & 2 & 53 & 55 \\
education? & Secondary & 30 & 87 & 117 \\
Total & Tertiary & 118 & 2 & 120 \\
\hline
\end{tabular}

Most of the respondents had attained some level of education. $120(40 \%)$ had tertiary education $(98.3 \%$ from Parklands and $1.7 \%$ from Kawama), 117 (39\%) had secondary education $(25.6 \%$ from Parklands and $74.4 \%$ from Kawama) and 55 (18.3\%) had primary education (3.6\% from Parklands and $96.4 \%$ from Kawama). Only 8 (2.7\%) of the participants had no formal education ( $0 \%$ from Parklands and $100 \%$ from Kawama). Chi square value: 1.95 and $\mathrm{P}$ - value: 0.000

\subsubsection{Frequency Distribution of Occupation}

Majority of the respondents in this study were unemployed 142 (47.3\%) [39.4\% from Parklands and 60.6\% from Kawama], 106 (35.3\%) were self-employed (40.6\% from Parklands and 59.4\% from Kawama) and 52 (17.3\%) were in formal employment $(98.1 \%$ from Parklands and $1.9 \%$ from Kawama). Chi square value: 58.189 and $\mathrm{P}$ - value: 0.000

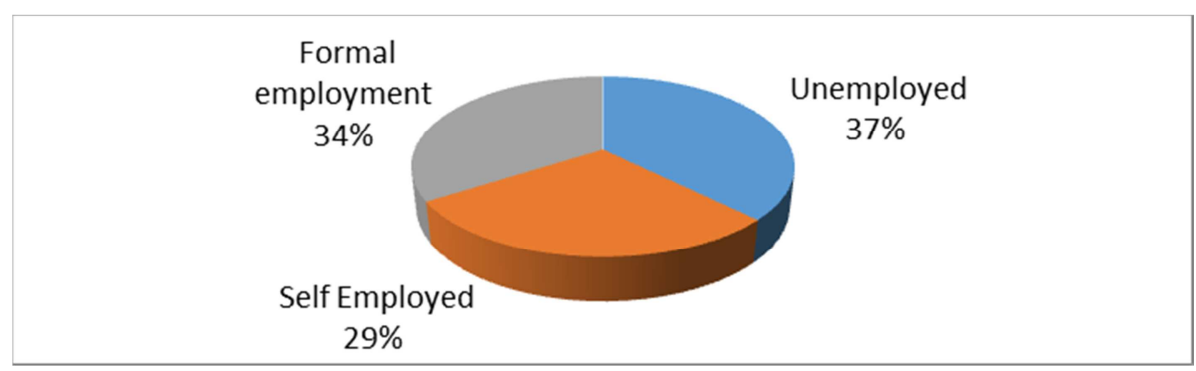

Figure 2. Distribution of Occupation.

\subsubsection{Frequency of Distribution of Religion}

Table 3. Distribution of Religion.

\begin{tabular}{lllll}
\hline & & \multicolumn{2}{l}{ Residence } & \\
\cline { 3 - 4 } & & $\begin{array}{l}\text { Parklands } \\
\text { (Urban) }\end{array}$ & $\begin{array}{l}\text { Kawama } \\
\text { (Rural) }\end{array}$ & Total \\
\hline \multirow{2}{*}{ What is your } & Catholic & 30 & 42 & 72 \\
religious & Jehovah's witness & 20 & 39 & 59 \\
denomination? & Pentecostal & 84 & 45 & 129 \\
& Others & 16 & 24 & 40 \\
Total & & 150 & 150 & 300 \\
\hline
\end{tabular}

All the participants belonged to religious organizations.
The majority, 129 (43\%) were Pentecostals $(65.1 \%$ from Parklands and $34.9 \%$ from Kawama), 72 (24\%) were Catholics (41.7\% from Parklands and 58.3\% from Kawama), 59 (19.7\%) were Jehovah's witnesses $(33.9 \%$ from Parklands and $66.1 \%$ from Kawama) and $40(13.3 \%)$ belonged to other religions (40\% from Parklands and 60\% from Kawama). Chi square value: 21.509 and $\mathrm{P}$ - value: 0.000

\subsection{Knowledge Based Questions on BC and CBE}

QA1. Have you ever heard of Clinical Breast Examination (CBE)?

All the participants $300(100 \%)$ had heard about CBE?

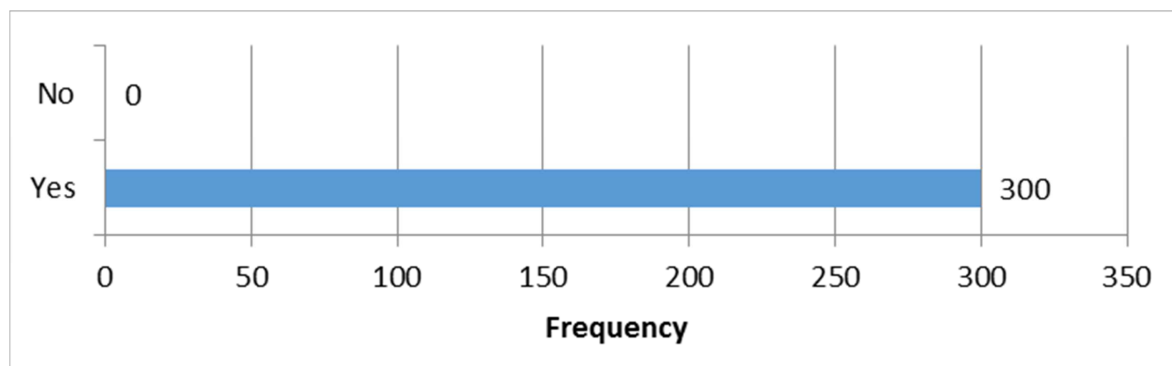

Figure 3. Number of women who have heard of $C B E$.

QA2. Where did you get your information on CBE?

$147(49 \%)$ of the participants had heard about CBE from TV/Radio, 231 (77\%) from friends, 165 (55\%) from print media, 183 (61\%) from social media, 154 (51.3\%) from health workers and 164 (54.7\%) from other sources.
Table 4. Sources of information on $C B E$.

\begin{tabular}{lll}
\hline Source of information & Frequency & Percent \\
\hline TV/Radio & 147 & 49 \\
Friend & 231 & 77 \\
Print Media & 165 & 55 \\
Social Media & 183 & 61 \\
Health Worker & 154 & 51.3 \\
Other & 164 & 54.7 \\
\hline
\end{tabular}


QA3. In your own words what is CBE?

$262(87.3 \%)$ of the respondents were able to explain correctly what CBE was (53.7\% from Parklands and $42.7 \%$ from Kawama) while $38(12.7 \%)$ were not $(0 \%$ from Parklands and $100 \%$ from Kawama). The Chi square value was 43.511 and $\mathrm{P}$ - value was 0.000

Table 5. Responses for definition of $C B E$.

\begin{tabular}{|c|c|c|c|c|}
\hline & & \multicolumn{2}{|l|}{ Residence } & \multirow[b]{2}{*}{ Total } \\
\hline & & $\begin{array}{l}\text { Parklands } \\
\text { (Urban) }\end{array}$ & $\begin{array}{l}\text { Kawama } \\
\text { (Rural) }\end{array}$ & \\
\hline \multirow{3}{*}{$\begin{array}{l}\text { In your own words } \\
\text { what is Clinical } \\
\text { Breast Examination? } \\
\text { Total }\end{array}$} & Wrong & 0 & 38 & 38 \\
\hline & Correct & 150 & 112 & 262 \\
\hline & & 150 & 150 & 300 \\
\hline
\end{tabular}

QA4. What do you think are the cause(s) of Breast Cancer?

$210(70 \%)$ of the subjects were able to correctly identify the causes of breast cancer $(71.4 \%$ from Parklands and $28.6 \%$ from Kawama) while $90(30 \%)$ were not $(0 \%$ from Parklands and $100 \%$ from Kawama). The Chi square value was 1.286 and $\mathrm{P}$ - value was 0.000

Table 6. Causes of breast cancer.

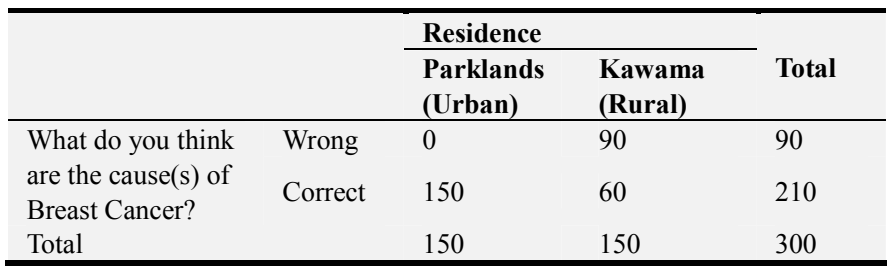

QA5. What are the risk factor(s) for Breast cancer?

All the participants were able to identify some risk factors for breast cancer. However, women from Parklands identified more risk factors when compared with women from Kawama. The Chi square value was 1.528 and $\mathrm{P}$ - value was 0.000 .

Table 7. Reponses to risk factors of breast cancer.

\begin{tabular}{|c|c|c|c|c|}
\hline & & \multicolumn{2}{|l|}{ Residence } & \multirow[b]{2}{*}{ Total } \\
\hline & & $\begin{array}{l}\text { Parklands } \\
\text { (Urban) }\end{array}$ & $\begin{array}{l}\text { Kawama } \\
\text { (Rural) }\end{array}$ & \\
\hline \multirow{8}{*}{$\begin{array}{l}\text { Number of Risk } \\
\text { factors Identified }\end{array}$} & 1 & 0 & 29 & 29 \\
\hline & 2 & 1 & 42 & 43 \\
\hline & 3 & 4 & 19 & 23 \\
\hline & 4 & 13 & 18 & 31 \\
\hline & 5 & 27 & 13 & 40 \\
\hline & 6 & 12 & 5 & 17 \\
\hline & 7 & 88 & 10 & 98 \\
\hline & 8 & 5 & 14 & 19 \\
\hline Total & & 150 & 150 & 300 \\
\hline
\end{tabular}

QA6. What are the symptom(s) of Breast Cancer?

All the respondents were able to identify some signs and symptoms of breast cancer. However, women from Parklands recognized more signs and symptoms when compared with women from Kawama. The Chi square value was 1.926 and $\mathrm{P}$ - value was 0.000
Table 8. Reponses to symptoms of breast cancer.

\begin{tabular}{lllll}
\hline & & Residence & \\
\cline { 2 - 4 } & & $\begin{array}{l}\text { Parklands } \\
\text { (Urban) }\end{array}$ & $\begin{array}{l}\text { Kawama } \\
\text { (Rural) }\end{array}$ & Total \\
\hline & 2 & 2 & 15 & 17 \\
Number of signs and & 3 & 9 & 40 & 49 \\
symptoms of Breast & 4 & 19 & 93 & 112 \\
Cancer identified. & 5 & 27 & 0 & 27 \\
& 6 & 93 & 2 & 95 \\
Total & & 150 & 150 & 300 \\
\hline
\end{tabular}

QA7. Do you think Breast Cancer can be prevented or cured if detected early?

293 (97.7\%) of the participants thought that Breast Cancer can be prevented or cured (51.2\% from Parklands and $48.8 \%$ from Kawama) while 7 (2.3\%) did not (0\% from Parklands and $100 \%$ from Kawama). The Chi square value was 7.167 and $\mathrm{P}$ - value was 0.007 .

Table 9. Reponses to whether breast cancer can be cured or prevented.

\begin{tabular}{lllll}
\hline & & Residence & \\
\cline { 2 - 4 } & & $\begin{array}{l}\text { Parklands } \\
\text { (Urban) }\end{array}$ & $\begin{array}{l}\text { Kawama } \\
\text { (Rural) }\end{array}$ & Total \\
\hline $\begin{array}{l}\text { Do you think Breast Cancer } \\
\text { can be prevented or cured if }\end{array}$ & No & 0 & 7 & 7 \\
$\begin{array}{l}\text { detected early? } \\
\text { Total }\end{array}$ & Yes & 150 & 143 & 293 \\
\hline
\end{tabular}

QA8. How can breast cancer be prevented?

All the subjects were able to identify some ways of preventing breast cancer. However, women who resided in Parklands identified more methods than women who resided in Kawama. The Chi square value was 2.066 and $\mathrm{P}$ - value was 0.000 .

Table 10. Methods of breast cancer prevention.

\begin{tabular}{lllll}
\hline & & Residence & \\
\cline { 2 - 4 } & & $\begin{array}{l}\text { Parklands } \\
\text { (Urban) }\end{array}$ & $\begin{array}{l}\text { Kawama } \\
\text { (Rural) }\end{array}$ & Total \\
\hline Number of way of & 1 & 2 & 102 & 104 \\
preventing breast & 2 & 0 & 23 & 23 \\
cancer identified. & 3 & 62 & 11 & 73 \\
& 4 & 86 & 14 & 100 \\
Total & & 150 & 150 & 300 \\
\hline
\end{tabular}

\subsection{Level of Knowledge of BC and CBE}

Level of knowledge was measured using 7 questions on Breast Cancer and Clinical Breast Examination (See Question QA1, QA3, QA4, QA5, QA6, QA7, and QA8 above). These questions had a total of 23 marks. A mark was given for a right answer and no mark was given for a wrong answer. Respondents who scored 17 - 23 marks were considered to have good knowledge, those who scored between 12 - 16 marks were considered to have average knowledge and those who scored $0-11$ marks had poor knowledge. Veena et al (2015) had used the same method to measure knowledge in their study. In this study, 149 (49.7\%) of the respondents had good knowledge (94.6\% from Parklands and 5.4\% from Kawama), 67 (22.3\%) have average knowledge (13.4\% from Parklands and 86.6\% from 
Kawama) and $84(28 \%)$ had poor knowledge ( $0 \%$ from Parklands and $100 \%$ from Kawama). P - Value was 0.00 and Chi - square value was 2.386

Table 11. Level of Knowledge of BC and CBE.

\begin{tabular}{lllll}
\hline & & Residence & \\
\cline { 3 - 4 } & & $\begin{array}{l}\text { Parklands } \\
\text { (Urban) }\end{array}$ & $\begin{array}{l}\text { Kawama } \\
\text { (Rural) }\end{array}$ & Total \\
\hline Knowledge & Good & 141 & 8 & 149 \\
Classification BCS & Average & 9 & 58 & 67 \\
Total & Poor & 0 & 84 & 84 \\
\hline
\end{tabular}

\subsection{Attitude Towards CBE}

Attitude was measured by asking respondents if they would undergo $\mathrm{CBE}$ and if they would encourage their fellow female friends and family to go for CBE at a Health Facility? There results revealed that 289 (96.3\%) of the respondents $(51.2 \%$ from Parklands and $48.8 \%$ from Kawama) showed good attitude and 11 (3.7\%) showed poor attitude (1.8\% from Parklands and 98.2\% from Kawama). P Value was 0.032 and $\mathrm{Chi}$ - square value was 4.624 .

Table 12. Attitude towards $C B E$

\begin{tabular}{lllll}
\hline & & \multicolumn{2}{l}{ Residence } & \\
\cline { 3 - 4 } & & $\begin{array}{l}\text { Parklands } \\
\text { (Urban) }\end{array}$ & $\begin{array}{l}\text { Kawama } \\
\text { (Rural) }\end{array}$ & Total \\
\hline \multirow{2}{*}{ Attitude } & Yes & 148 & 141 & 289 \\
Total & No & 2 & 9 & 11 \\
& & 150 & 150 & 300 \\
\hline
\end{tabular}

\subsection{Practice of $\mathrm{CBE}$}

Practice was measured by asking respondents if they have been screened for Breast cancer before at a health facility.

There results revealed that only $36(12 \%)$ of the participants (97.2\% from Parklands and 2.8\% from Kawama) showed good practice towards CBE and 264 (88\%) showed bad practice $(43.6 \%$ from Parklands and $56.4 \%$ from Kawama). P - Value was 0.00 and $\mathrm{Chi}$ - square value was 36.49

Table 13. Practice of $C B E$.

\begin{tabular}{lllll}
\hline & & Residence & \\
\cline { 3 - 4 } & & $\begin{array}{l}\text { Parklands } \\
\text { (Urban) }\end{array}$ & $\begin{array}{l}\text { Kawama } \\
\text { (Rural) }\end{array}$ & Total \\
\hline Practice towards & Good & 35 & 1 & 36 \\
CBE & Bad & 115 & 149 & 264 \\
Total & & 150 & 150 & 300 \\
\hline
\end{tabular}

\subsection{Knowledge Based Questions on Self Breast Examination}

QB1. Have you ever heard of self-breast examination?

$173(57.7 \%)$ of the respondents had heard about Self Breast Examination before the day of the interview (85.5\% from Parklands and 14.5\% from Kawama) while 127 (42.3\%) had not (1.6\% from Parklands and 98.4\% from Kawama). P Value was 0.00 and Chi - square value was 2.066.

Table 14. Self breast examination.

\begin{tabular}{lllll}
\hline & & \multicolumn{2}{l}{ Residence } & \\
\cline { 3 - 4 } & & $\begin{array}{l}\text { Parklands } \\
\text { (Urban) }\end{array}$ & $\begin{array}{l}\text { Kawama } \\
\text { (Rural) }\end{array}$ & Total \\
\hline Have you ever heard of & No & 2 & 125 & 127 \\
self-breast examination? & Yes & 148 & 25 & 173 \\
Total & & 150 & 150 & 300 \\
\hline
\end{tabular}

QB2. In your own words, what is self - breast examination?

$141(47 \%)$ of the respondents were able to explain correctly what Self Breast Examination was (85.8\% from Parklands and 14.2\% from Kawama) while 159 (53\%) were not (18.2\% from Parklands and $81.8 \%$ from Kawama). The Chi square value was 1.365 and $\mathrm{P}$ - value was 0.000

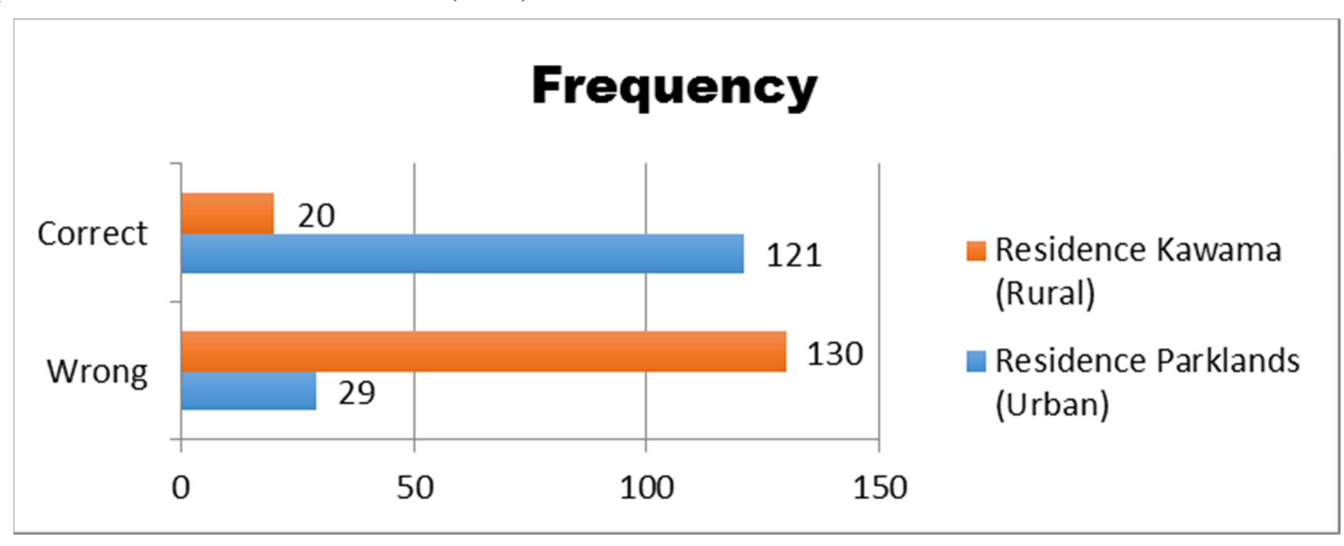

Figure 4. Correct definition of breast cancer.

QB3. How often should self-breast examination be done?

$149(49.7 \%)$ of the subjects were able to state correctly how often SBE should be done $(77.9 \%$ from Parklands and
$22.1 \%$ from Kawama) while 151 (50.3\%) were not $(22.5 \%$ from Parklands and $77.5 \%$ from Kawama). The Chi square value was 91.856 and $P$ - value was 0.000 


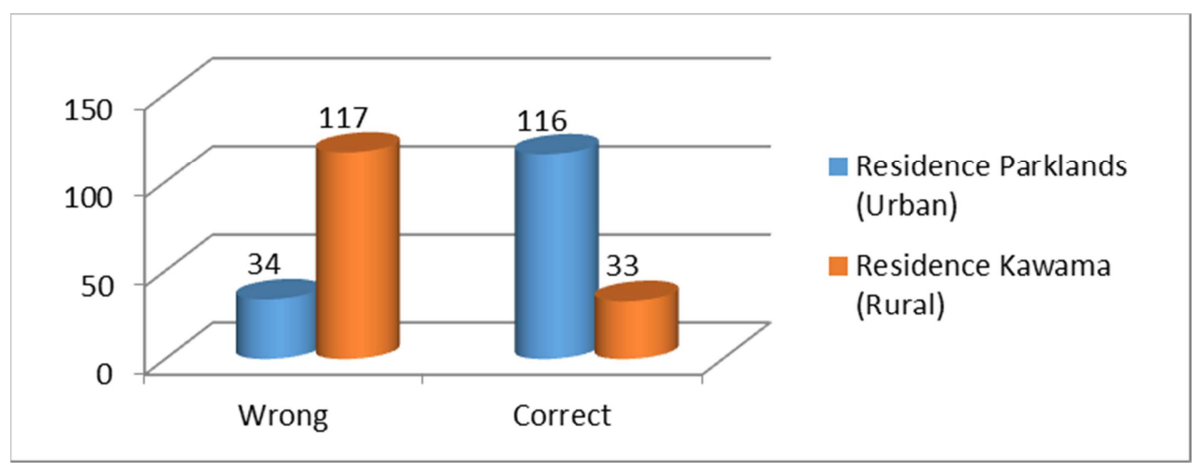

Figure 5. Frequency of self-breast examination.

QB4. What sign(s) do you look for when doing self-breast examination?

Table 15. Sign(s) to look for when doing self-breast examination.

\begin{tabular}{lllll}
\hline & & \multicolumn{2}{l}{ Residence } & Total \\
\cline { 2 - 4 } & & $\begin{array}{l}\text { Parklands } \\
\text { (Urban) }\end{array}$ & $\begin{array}{l}\text { Kawama } \\
\text { (Rural) }\end{array}$ & Tran \\
\hline Number of signs to look & 0 & 12 & 117 & 129 \\
for when doing self-breast & 1 & 4 & 28 & 32 \\
examination identified & 5 & 134 & 5 & 139 \\
Total & & 150 & 150 & 300 \\
\hline
\end{tabular}

$139(46.3 \%)$ of the participants were able to identify 5 signs to look for during SBE (96.4\% from Parklands and
$3.6 \%$ from Kawama) and $32(10.7 \%)$ identified 3 signs (12.5\% from Parklands and $87.5 \%$ from Kawama). 129 $(43 \%)$ did not know any sign to look for during SBE $(9.3 \%$ from Parklands and $90.7 \%$ from Kawama). The Chi square value was 2.232 and $\mathrm{P}$ - value was 0.000 .

QB5. What is the reason for doing self-breast examination?

$118(39 \%)$ of the subjects were able to explain correctly the reason for SBE $(98.3 \%$ from Parklands and $1.7 \%$ from Kawama) while $182(60.7 \%)$ were not (18.7\% from Parklands and $81.3 \%$ from Kawama). The Chi square value was 1.815 and $\mathrm{P}$ - value was 0.000

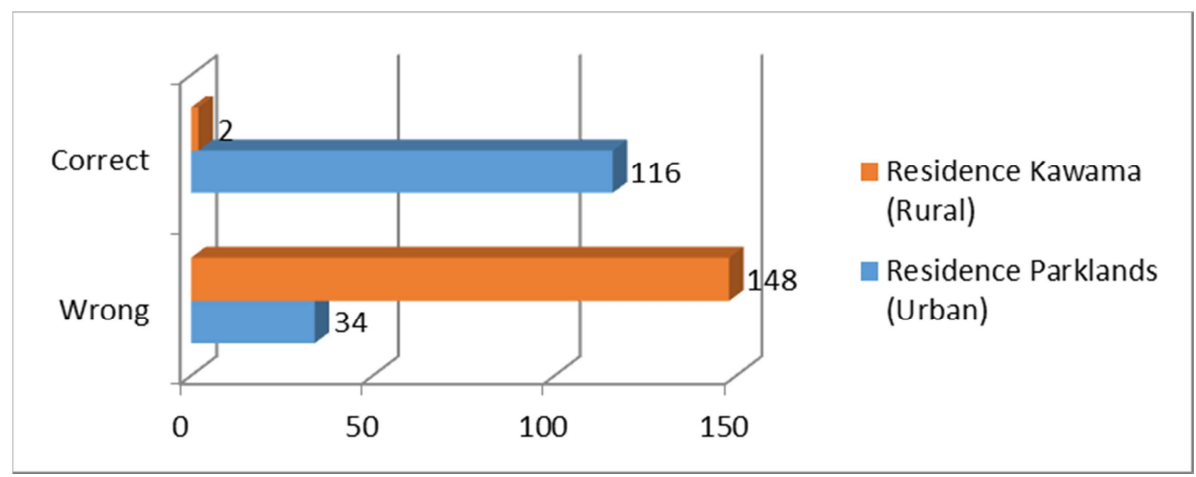

Figure 6. Reason for doing self-breast examination.

\subsection{Level of Knowledge of SBE}

Level of knowledge of SBE was measured using 5 questions which had a total of 23 marks (See Question QB1, QB2, QB3, QB4 and QB5 above). A mark was given for a right answer and no mark was given for a wrong answer. Participants who scored $7-9$ marks were considered to have good knowledge, those who scored between 5-6 marks were considered to have average knowledge and those who scored $0-4$ marks had poor knowledge. In this study, 135 (45\%) of the respondents had good knowledge $(97.8 \%$ from Parklands and 2.2\% from Kawama), 4 (1.3\%) had average knowledge $(50 \%$ from Parklands and $50 \%$ from Kawama) and $161(53.7 \%)$ had poor knowledge $(9.9 \%$ from Parklands and $89.1 \%$ from Kawama). P - Value was 0.00 and Chi square value was 2.266 .
Table 16. Knowledge of SBE.

\begin{tabular}{lllll}
\hline & & Residence & \\
\cline { 3 - 4 } & & $\begin{array}{l}\text { Parklands } \\
\text { (Urban) }\end{array}$ & $\begin{array}{l}\text { Kawama } \\
\text { (Rural) }\end{array}$ & Total \\
\hline Knowledge & Good & 132 & 3 & 135 \\
Classification SBE & Average & 2 & 2 & 4 \\
Total & Poor & 16 & 145 & 161 \\
\hline
\end{tabular}

\subsection{Attitude Towards SBE}

Attitude was assessed by asking participants if they would be conducting SBE on themselves at specified times. The results revealed that $283(94.3 \%)$ of the respondents $(51.2 \%$ from Parklands and $48.8 \%$ from Kawama) showed good attitude and $17(5.7 \%)$ showed poor attitude $(2.9 \%$ from Parklands and $97.1 \%$ from Kawama). P - Value was 0.08 and Chi - square value was 3.055 
Table 17. Attitude towards SBE.

\begin{tabular}{lllll}
\hline & & Residence & \multirow{2}{*}{ Total } \\
\cline { 3 - 4 } & & Parklands (Urban) & Kawama (Rural) & \\
\hline \multirow{2}{*}{ Attitude } & Yes & 145 & 138 & 283 \\
Notal & No & 5 & 12 & 17 \\
\hline
\end{tabular}

\subsection{Practices of $S B E$}

Table 18. Practices of SBE.

\begin{tabular}{lllll}
\hline & & \multicolumn{2}{l}{ Residence } & \multirow{2}{*}{ Total } \\
\cline { 3 - 4 } & & Parklands (Urban) & Kawama (Rural) & \\
\hline \multirow{2}{*}{ Practice } & Good & 146 & 22 & 168 \\
\multirow{2}{*}{ Total } & Bad & 4 & 128 & 132 \\
\hline
\end{tabular}

Practice was measured by asking respondents if they perform SBE. It was found that $168(56 \%)$ of the participants (86.9\% from Parklands and 13.1\% from Kawama) showed good practice towards SBE and 132 (44\%) showed bad practice (3\% from Parklands and 97\% from Kawama). P Value was 0.00 and Chi - square value was 2.080.

\subsection{Relationships Between Variables of Interest (P-Value)}

Bivariate analysis was performed on demographic variable and KAP variables of CBE and SBE. The significance level was set at 0.05 and all $\mathrm{P}$ - values less than 0.05 were considered to be statistically important. Some positive relationships were observed. For example, level of education showed significant relationships with Practice of CBE (P value: 0.00), Practice of SBE (P- Value: 0.00), level of knowledge of CBE (P - value: 0.00) and level of knowledge of SBE (P - Value: 0.00). Also, level of Knowledge of CBE correlated significantly with practice of $\mathrm{CBE}(\mathrm{P}$ - value: $0.00)$ and level of Knowledge of SBE correlated significantly with practice of SBE (P - value: 0.00). However, attitude towards $\mathrm{CBE}$ did not seem to show any significant relationship with practice of $\mathrm{CBE}(\mathrm{P}-$ Value: 0.522$)$. Attitude towards SBE also did not show a significant relationship with practice of SBE (P - Value: 0.182).

Table 19. Relationships between variables of interest (P-VALUE).

\begin{tabular}{|c|c|c|c|c|c|c|}
\hline & $\begin{array}{l}\text { Attitude } \\
\text { towards CBE }\end{array}$ & $\begin{array}{l}\text { CBE } \\
\text { Practice }\end{array}$ & SBE Practice & $\begin{array}{l}\text { Attitude } \\
\text { towards SBE }\end{array}$ & $\begin{array}{l}\text { Level of } \\
\text { Knowledge of CBE }\end{array}$ & $\begin{array}{l}\text { Level of } \\
\text { Knowledge of SBE }\end{array}$ \\
\hline Age & .551 & .014 & .404 & .551 & .029 & .038 \\
\hline Marital status & .290 & .830 & .006 & .290 & .237 & .219 \\
\hline Level of education & .293 & .000 & .000 & .293 & .000 & .000 \\
\hline Occupation & .019 & .051 & .000 & .019 & .000 & .000 \\
\hline Religious denomination & .361 & .244 & .281 & .361 & .369 & .104 \\
\hline Attitude towards CBE & & .522 & .182 & .000 & .225 & .061 \\
\hline SBE Practice & .182 & .000 & & .182 & .000 & .000 \\
\hline Attitude towards SBE & .000 & .522 & .182 & & .225 & .061 \\
\hline Level of Knowledge towards CBE & .225 & .000 & .000 & .225 & & .000 \\
\hline Level of Knowledge towards SBE & .061 & .000 & .000 & .061 & .000 & \\
\hline
\end{tabular}

\section{Discussion, Recommendations, and Conclusion}

\subsection{Demographics Characteristics of Women from Parklands and Kawama Areas}

The study had an equal number of participants from both Parklands (urban area) and Kawama (rural area). A total of 300 women were interviewed and their ages ranged from 18 to 60 years. The mean age of participants was almost the same for the two regions (37.26 years for Parklands and 40.08 years for Kawama). Majority of the participants $(34.3 \%)$ were between the ages of 36 and 45 years. Most of these resided in Parklands (59.2\%). 33.7\% of the women were above the age of 45 (32.7\% from Parklands and $67.3 \%$ from Kawama). Furthermore, most of the respondents had attained some level of education. $40 \%$ had tertiary education (98.3\% from Parklands and 1.7\% from Kawama), 39\% had secondary education (25.6\% from Parklands and 74.4\% from Kawama) and $18.3 \%$ had primary education (3.6\% from Parklands and $96.4 \%$ from Kawama). Only 8 (2.7\%) of the participants had no formal education ( $0 \%$ from Parklands and $100 \%$ from Kawama). This finding is interesting because the high number of participants with formal education could indicate that these individuals are well informed about breast cancer and the importance of being screened for it. However, respondents from Parklands could be more knowledgeable about BCS and SBE since most of them had attained the highest level of education. These results are similar to what previous studies have shown $[19,20]$ Majority of the respondents in this study were unemployed (47.3\%). Of these $39.4 \%$ were residents of Parklands and $60.6 \%$ were residents of Kawama. This result reveals that the unemployment level among women is high in Kitwe especially among those residing in rural areas. This finding could be associated with the low levels of education among rural dwellers. Thus it is important that education for the girl child is promoted to the greatest possible degree because through education women will learn more about their health (including importance of Breast Cancer Screening) and will also maximize their chances of finding employment. Finally, all the participants belonged to religious organizations. This is a good sign and religious organizations should take advantage of it. These organizations should be playing a role in encouraging women 
on health issues especially the importance of being screened for breast cancer.

\subsection{Knowledge About BC and $C B E$}

In this study knowledge was related to what women knew about breast cancer and clinical breast examination, in terms of breast cancer definition, predisposing factors and causes, signs and symptoms, prevention and awareness of CBE and its importance. The study revealed that all the participants $(100 \%)$ from both rural and urban area had heard about Clinical Breast Examination. Most of these (77\%) had heard about CBE from friends. This results shows that women in Kitwe district are doing a great job in educating one another on the issues of women's health. Other sources also played a great role in disseminating information about CBE. For example, $49 \%$ of the participants had heard about CBE from TV/Radio, $61 \%$ from social media and $51.3 \%$ from health workers. These results are better when compared to a study by [17] were only $15 \%$ of women had heard of CBE. The difference could be due to differences in socio - demographic characteristics. Some of these sources of information have also been identified in several studies. For example, one study found that the leading source of information about breast cancer was "elders, neighbours and friends [21]. Other studies recognised the media and health workers [22, 14]. Furthermore, out all the respondents who had heard about CBE, only $87.3 \%$ of them were able to explain correctly what it was. Of these $53.7 \%$ were from Parklands and $42.7 \%$ from Kawama. The difference could be due to differences in the level of education. Likewise, $70 \%$ of the subjects were able to correctly identify the causes of breast cancer. This number consisted of $71.4 \%$ of the participants from Parklands and $28.6 \%$ from Kawama. Also, all the women in this study were able to identify some risk factors for breast cancer as well as the signs and symptoms of the disease. However, women from Parklands identified more risk factors and signs and symptoms when compared with women from Kawama. In addition, $97.7 \%$ of the participants thought that Breast Cancer can be prevented or cured $(51.2 \%$ from Parklands and $48.8 \%$ from Kawama) and all the women were able to identify some ways of preventing breast cancer even though women who resided in Parklands identified more methods than women who stayed in Kawama.

These results are better than what was found in a study in Iran were complete awareness about risk factors for breast cancer and signs and symptoms was very low [23]. However, these findings call for urgent educational interventions for women in rural areas. In this day and age, women are expected to be well informed about diseases like breast cancer, its causes, risk factors, signs and symptoms, and prevention and treatment. If women are educated about these, mortality due to breast cancer will reduce to the greatest possible degree. Overall, the study found that most of the respondents had adequate knowledge about breast cancer and clinical breast examination, especially those residing in Parklands (Urban).49.7\% of the respondents had good knowledge (94.6\% from Parklands and 5.4\% from Kawama) and $22.3 \%$ had average knowledge (13.4\% from Parklands and $86.6 \%$ from Kawama). With regard to knowledge about breast cancer, a study conducted in Zambia in 2007, found that $58 \%$ of participants in the urban area had no knowledge compared to $82 \%$ of the rural women. Significant differences in knowledge were observed between the two groups of women $(\mathrm{P}<0.000)$. Women in urban area were more knowledgeable about breast cancer than rural women [19]. The results of the current study are better than those found by [17]. However, $28 \%$ of the women having poor knowledge ( $0 \%$ from Parklands and 100\% from Kawama) is still a huge problem and indicate the need for educational programs in rural areas.

\subsection{Attitude Towards CBE}

The study revealed that most of the respondents had good (positive) attitude towards Clinical Breast Examination $(96.3 \%)$. This was in line with what [23] in their study.

\subsection{Practice of $\mathrm{CBE}$}

Practice of CBE was not good. Results revealed that only $12 \%$ of the participants $(97.2 \%$ from Parklands and $2.8 \%$ from Kawama) showed good practice while $88 \%$ showed bad practice (43.6\% from Parklands and 56.4\% from Kawama). These results were slightly better than what was found in a study by [17] were only $8 \%$ of the women practiced CBE. However, these results are very poor when compared with a similar study, were annual CBE rate was $45 \%$ in educated women [17]. In the current study it was interesting to note that women from urban areas had better practice towards CBE. This could indicate that having good knowledge and attitude may determine women's practice of CBE. Nevertheless, the overall number of women undergoing CBE was too low and indicates the urgent need for massive sensitization programs on the importance of being screened. These programs should target all women (rural and urban) with special attention to those in the reproductive age.

\subsection{Knowledge of Self Breast Examination}

The results of the study indicate that $57.7 \%$ of the respondents had heard about Self Breast Examination before the day of the interview (85.5\% from Parklands and $14.5 \%$ from Kawama), $47 \%$ of the participants were able to explain correctly what Self Breast Examination was $(85.8 \%$ from Parklands and $14.2 \%$ from Kawama). However, only $39 \%$ of the subjects were able to explain correctly the reason for performing. Likewise, $49.7 \%$ of the subjects were able to state correctly how often SBE should be done $77.9 \%$ from Parklands and $22.1 \%$ from Kawama). These findings are better than those found by [24] were only $38.9 \%$ of the participants had heard of SBE and $0.4 \%$ knew the correct frequency of BSE. Additionally, $46.3 \%$ of the participants were able to identify 5 signs to look for during SBE (96.4\% from Parklands and $3.6 \%$ from Kawama) and $10.7 \%$ identified 3 signs (12.5\% from Parklands and $87.5 \%$ from Kawama). However, $43 \%$ did not know any of the signs to 
look for during SBE (9.3\% from Parklands and 90.7\% from Kawama). These results are similar to what is in the literature [25]. Overall, $45 \%$ of the respondents had good knowledge about SBE (97.8\% from Parklands and 2.2\% from Kawama), $1.3 \%$ had average knowledge (50\% from Parklands and 50\% from Kawama) and 53.7\% had poor knowledge (9.9\% from Parklands and $89.1 \%$ from Kawama). A similar study highlighted that $57.4 \%$ of women in urban area and $82.7 \%$ of women in rural areas had no knowledge about SBE [19]. Both of these studies showed significant differences in BSE knowledge between the urban and rural areas. Women from urban area had more knowledge on BSE than women from rural area. In general, both studies showed low level of knowledge of SBE. Lack of knowledge of SBE has serious consequences on practice [17]. Women should be well educated on this subject. Information on SBE and Breast Cancer could be communicated to women during antenatal and postnatal clinic visits and through electronic and print media. [20] Think that education on breast cancer would teach women the benefits of breast self-examination and can promote early diagnosis of the condition.

\subsection{Attitude Towards SBE}

The study results show that $94.3 \%$ of the respondents (51.2\% from Parklands and 48.8\% from Kawama) showed good (positive) attitude towards SBE. These results are quite impressive when compared with studies by [26] and [27] were $74.4 \%$ and $75 \%$ of their participants had positive attitude towards SBE. These results still call for interventions that will channel the positive attitudes into practice.

\subsection{Practice of SBE}

In this study, it was found that only $56 \%$ of the participants (86.9\% from Parklands and $13.1 \%$ from Kawama) practiced SBE. Several studies have produced similar results. A study by [19] showed that BSE was low in both urban and rural areas as $65.5 \%$ of women in rural and $59 \%$ of women in urban area did not practice BSE. Lombe (2017) found that only $28.2 \%$ of the participants actually practiced BSE. Another study by [27] revealed that only $48.3 \%$ of the women practised BSE. The most common reason for not practicing BSE cited in all these studies was lack of knowledge of how to perform the technique correctly [26, 27]; and [19]. The finding of this study is supported by these studies. Educational interventions still remain the best method to improve women's knowledge on SBE and eventually improve practice.

\subsection{Relationships Between Variables of Interest}

The study revealed that level of education showed significant relationships with Practice of CBE (P - value: 0.00), Practice of SBE (P- Value: 0.00), level of knowledge of CBE (P - value: 0.00$)$ and level of knowledge of SBE (P Value: 0.00). Also, level of Knowledge of CBE correlated significantly with practice of CBE (P - value: 0.00$)$ and level of Knowledge of SBE correlated significantly with practice of SBE (P - value: 0.00). However, attitude towards CBE did not seem to show any significant relationship with practice of CBE (P - Value: 0.522). Attitude towards SBE also did not show a significant relationship with practice of SBE (P Value: 0.182). These results are similar to what is in the literature $[26,17,27,19]$ and $[20]$.

\section{Conclusion}

The findings of the study showed that most of rural than urban women had poor knowledge about breast cancer, CBE and SBE. A significant difference in knowledge levels on breast cancer, Clinical Breast Examination and Self Breast Examination was observed between women from urban and rural areas. However, practice of $\mathrm{CBE}$ and SBE was poor in both rural and urban areas. The study concluded that even though a knowledge and attitude gap exist between women in rural and those in urban areas, they are both poor at practicing SBE and CBE. Hence, there is need for more educational programs on breast cancer and SBE and they should be conducted in print and electronic media using the local languages to reach out to the women in rural areas.

\section{Recommendations}

After taking into consideration research findings, the following recommendations were made. To begin with, the government of Zambia through the Ministry of Health should conduct educational programmes on breast cancer and SBE. These programmes should be conducted in print and electronic media using the local languages to reach out to the women in rural areas. Furthermore, the Zambian school curricula should include lessons on breast cancer, clinical breast examination and self-breast examination. If this comes to fruition, girls will be sensitized at an early age. Likewise, non-governmental organizations should help fund the Ministry of Health so that they create teaching aids and manuals for use by health workers. This will ensure that adequate up to date information on Breast cancer and SBE is given to women in both rural and urban areas. Lastly, other researchers are encouraged to expand on this topic by conducting it on a large scale. Researcher should also include men in these studies because breast cancers not only affect men but also women.

\section{Abbreviations}

$\begin{array}{ll}\text { BC } & \text { Breast Cancer } \\ \text { SBE } & \text { Self Breast Examination } \\ \text { CBE } & \text { Clinical Breast Examination } \\ \text { KAP } & \text { Knowledge Attitude and Practice } \\ \text { WHO } & \text { World Health Organization } \\ \text { MoH } & \text { Ministry of Health } \\ \text { CUPP } & \text { Continuous Update Project } \\ \text { ACS } & \text { American Cancer Society } \\ \text { CCS } & \text { Canadian Cancer Society } \\ \text { HRT } & \text { Hormonal Replacement Therapy } \\ \text { ZNCR } & \text { Zambia National Cancer Registry }\end{array}$




\section{Acknowledgements}

I would like to express my profound gratitude to my supervisor Dr A. Sichilima for his unfailing and tireless dedication and continuous encouragement from the time of formulation of the title to finalization of this paper. Furthermore, I wish to thank all the women who willing took part in this study and made it a success. Special thanks also go to the Public Health Department CBU-MCS SOM, Ethics Review Committee at TDRC of Ndola Teaching Hospital, the Copperbelt Provincial Health Office and Kitwe District Health Office for giving me approval to conduct this research. Lastly I would like to acknowledge my friends Natasha Chileshe, Wilbroad Chilenga and Alexander Nherenzo for their time, advice and encouragements that greatly improved my work. Not forgetting my family for moral and financial support. Thank you.

\section{References}

[1] Doll R, Peto R. The Causes of cancer. Oxford, UK; Oxford university press; 1981.

[2] World health organization (2012), Breast Cancer Statistics. https://www.wcrf.org/dietandcancer/cancer-trends/breastcancer-startistics\&ved Accessed on 16th October, 2018.

[3] American Cancer Society (2011) Breast Cancer Signs and Symptoms. https://www.amp.cancer.org/\&ved.Accessed on 16th October, 2018.

[4] Peto R, Boreham J, Clarke M, Davies C, Beral V: UK and USA breast cancer deaths down $25 \%$ in year 2000 at ages 20 69 years. Lancet 2000, 355: 1822.

[5] Bray F, Sankila R, Ferlay J, Parkin DM: Estimates of cancer incidence and mortality in Europe in 1995. Eur J Cancer 2002, 38: 99-166.

[6] Mcpherson K, Steel CM, Dixon JM. Breast cancer epidemiology, risk factors and genetics, Brit Med J 2000; 321: 624-628.

[7] Carol K. K. (1975) Experimental evidence of dietary factors and hormone dependent cancers. Cancer Research. 35: 3374.

[8] Dunn J, Famdon S. R. (1991) Familial breast cancer. Journal of Royal College of Surgeons of Edinburgh. 36: 147-151.

[9] Lee-Fieldstein A, Anton-Culver H., Fieldstein P. J. (1994) Treatment differences and other prognostic factors related to breast cancer survival. JAMA. 271 1163-1168

[10] “American Cancer Association, Breast Cancer Survival Rates. https://www.amp.cancer.org/cancer/breastcancer/understanding-a-breast-diagnosis/breast-cancersurvival-rate.html. Accessed on $20^{\text {th }}$ October, 2018.

[11] Vorobiof DA, Abratt R (2007). The cancer burden in Africa. S. Afr. Med. J. 97: 937-939.

[12] Muchirevesi. S. S (2016). Knowledge and Practices of Breast Self-Examination among women admitted at a Private Clinic, Zimbabwe. Thesis Submitted in accordance with the Requirements for the Degree of Master of Arts in the Subject Health Studies at the University of South Africa.
[13] Weber and Kelly Muchirevesi. S. S (2016). Knowledge and Practices of Breast Self-Examination among women admitted at a Private Clinic, Zimbabwe. Thesis Submitted in accordance with the Requirements for the Degree of Master of Arts in the Subject Health Studies at the University of South Africa.

[14] Dündar. E. P, Özmen. D, Öztürk. B, Haspolat. G, Akyıldız. F, Coban. S and Cakıroğlu. G (2006). The knowledge and attitudes of breast self-examination and mammography in a group of women in a rural area in western Turkey. BioMed Central Ltd. http://www.biomedcentral.com/1471-2407/6/43 accessed on 25th October, 2018.

[15] Amoroto, Jean B, Antonio, Frances Rica D., Anua, Gemma B. Arriola, Daniel Ryan II M., Bagaporo, and John Allen M (2014). Breast Self-Examination: Awareness, Compliance, and Confidence of Lyceum of the Philippines University - Laguna Students. CAM Research Journal Vol 2 No. 1 September 2014.

[16] Erlewein, Joni L., "Rural Women's Participation in Breast Self-Examination" (1998). Masters Theses. 367. http://scholarworks.gvsu.edu/theses/367 accessed on24th October, 2018.

[17] Veena K. S, Kollipaka. R and Rekha R (2015). The Knowledge and attitude of breast self-examination and mammography among rural women. Int J Reprod Contracept Obstet Gynecol. 2015 Oct; 4 (5): 1511-1516. www.ijrcog.org accessed on $25^{\text {th }}$ October, 2018.

[18] Petro-Nustus. W and Mikhail. B (2002). Factors Associated with Breast Self-Examination among Jordanian Women. Public Health Nursing Vol. 19 No. 4, pp. 263-27107371209/02/\$15.00. Blackwell Publishing, Inc.

[19] Mukupo. F. C (2006). Breast Self-Examination Practices among Rural (Solwezi) and Urban (Lusaka). A Dissertation submitted to the University of Zambia in partial fulfilment of the requirement for the award of the Degree of Masters of Science in Mursing MSc $(\mathrm{N})$.

[20] Mukupo, FC and Mubita-Ngoma, CA. Breast Cancer Knowledge and Breast Self-Examination Practice among Rural and Urban Women in Zambia. Africa Journal of Nursing and Midwifery 9 (1) 2007 pp. 50-58.

[21] Veena D (2010). A Study to Assess the Knowledge and Attitude Regarding Breast Cancer and Breast SelfExamination among Women in Rural Phc of Tumkur, With A View to Develop Self Instructional Module" Proforma for Registration of Subjects For Community Health Nursing. Akshaya College of Nursing, Tumkur, Karnataka.

[22] Sideeq. K, Ayoub. T. T, and Khan. S. S. M (2017). Breast selfexamination: assessing its knowledge attitude and practice among ethnic Kashmiri females. Int J Community Med Public Health. $\quad 2017 \quad$ Sep; $4 \quad$ (9): $\quad 3288-3292$ http://www.ijcmph.comaccessed on 25th October, 2018.

[23] Iurigh. K. H, Majdi. M, Hajtalebi. H, Ghorbani. A and Hajtalebi. H (2016). Knowledge, Attitudes and Practices towards Breast Cancer Screening Programs among Iranian Rural Female Populations in North of Iran. International Journal of Life Science and Pharma Research. Vol 6/ Issue 2/April 2016.

[24] Obaji NC, Elom HA, Agwu UM, Nwigwe CG, Ezeonu PO, Umeora O (2013). Awareness and Practice of Breast SelfExamination among Market Women in Abakaliki, South East Nigeria. Ann Med Health Sci Res 2013; 3: 7-12. 
[25] Rosmawati. N. H. N (2010). Knowledge, Attitude and Practice of Breast Self-examination Among Women in a Suburban Area in Terengganu, Malaysia. Asian Pacific Journal of Cancer Prevention, Vol 11, 2010.

[26] Lombe. M. R (2017). Knowledge attitude and practice of breast-self-examination for early detectoin of breast cancer among women in roan constituency in luanshya, Copperbelt province, Zambia. Asian Pac. J. Health Sci., 2017; 4 (3): $74-$ 82 e-ISSN: 2349-0659, p-ISSN: 2350-0964.

[27] Alwan N. A. S, Al-Attar. W. M, Eliessa. R. A, Madfaie. Z. A and Tawfeeq. F. N (2012). Knowledge, attitude and practice regarding breast cancer and breast self-examination among a sample of the educated population in Iraq. Eastern Mediterranean Health Journal. 